\title{
TEMATI I PRIKAZI U ČASOPISU "GENERO" (2002-2016)
}

U postsocijalističkoj Srbiji sve je intenzivnije interesovanje za feminističku teoriju. Pored aktivističkog feminizma, čija je snažna antiratna inicijativa obeležila devedesete godine prošlog veka, formira se svest o neophodnosti feminističkog teorijskog pristupa, a ova ideja se konkretizuje 1991. godine pokretanjem Centra za ženske studije u Beogradu, koji svoj prvi eksperimentalni interdisciplinarni kurs u trajanju od jednog semestra simbolično počinje 8. marta 1992. godine. Već po nastanku Centra, kod njegovih članica postoji jasna ideja o pokretanju časopisa koji bi preveo i uveo feminističku teoriju u region (Ženske studije, a kasnije Genero). U ovom radu biće reči o nastanku i razvoju časopisa Genero, kao i o njegovoj strukturi. U prvom delu rada posebna pažnja biće posvećena tematima (detaljno će biti predstavljen temat Američka feministička kritika na osnovu kog ce se pokazati značaj prevođenja stranih teorijskih promišljanja za razvoj domaće feminističke teorije), dok će u fokusu drugog dela rada biti prikazi, uglavnom stručne literature.

Ključne reči: časopis Genero, prikazi, temati, feministička teorija, feministički časopisi u Srbiji 


\section{ISTORIJSKI KONTEKST I NASTANAK ČASOPISA "GENERO"}

Na prvi pogled se stiče utisak da je jedna velika socijalistička država morala da propadne da bi se u njenim državama-naslednicama otvorio prostor za istinski prodor feminističkih ideja sa zapada, za njihovo prenošenje na lokalno tlo, kao i za pokušaje njihovog praktičnog saobražavanja tom tlu. Međutim, to nipošto ne znači da su države nastale raspadom SFRJ, među kojima je i Srbija, otkrile zapadni feminizam "preko noći". Naprotiv, početkom devedesetih godina ovaj put je već bio prohodan zahvaljujući aktivistkinjama i aktivistima, istraživačicama i istraživačima koji su ove ideje razmenjivali i širili tokom socijalističkog perioda, počev od druge polovine sedamdesetih godina. ${ }^{1}$ Decenijama pre toga i uporedo s tim, sam jugoslovenski socijalistički projekat doprinosio je u ogromnoj (i danas, još uvek, verovatno nedovoljno ispitanoj i/ili priznatoj) meri emancipaciji žena i ustoličenju i poštovanju njihovih ljudskih prava. ${ }^{2}$

Ipak, početak sistematičnog bavljenja feminističkom teorijom, kao i pun zamah feminističke aktivističke inicijative, možemo locirati tek u prvim godinama poslednje decenije 20. veka. Ovaj početak ujedno predstavlja "otpor promenama koje su usledile tokom devedesetih godina" ${ }^{3}$ oličenim u razornoj i vulgarnoj, te u svojoj osnovi duboko maskulinoj nacionalističkoj ideologiji, ${ }^{4}$ koja je vrtoglavom brzinom

1 U tom pogledu, kao najznačajnije treba istaći sledeće aktivnosti: skup Drug-ca žena, novi pristup ženskom pitanju, održan 1978. godine u beogradskom SKC-u; objavljivanje temata "Studije o ženi i ženski pokret" u časopisu Marksizam u svetu 1981. godine (urednica Ljiljana Vuletić); objavljivanje temata "Žensko pismo" u zagrebačkoj Republici 1983. godine; dva skupa posvećena feminizmu održana u Dubrovniku 1986. i 1988.godine; objavljivanje temata "Žensko pismo" u časopisu Književnost LXXXIII, sv. 8-9 i dr.

2 Ovu tezu, između ostalih, zastupa i razrađuje i Jasmina Lukić u svom tekstu "Međugeneracijski dijalog kao način putovanja teorije" (Treća, tema broja "Re/generacijski feminizmi”, 2015 XVII 1-2): “[jer je] socijalistički režim kao deo svog ideološkog programa imao poseban uticaj na žene. Forme i konkretni učinci tog uticaja daleko su složeniji od onoga što je deo uobičajene slike bilo o socijalizmu bilo o tradiciji feminizma kada je reč o postsocijalističkim zemljama” (str. 25).

3 Biljana Dojčinović, "Prihvatanje razlika: feministička kritika u Srbiji u postsocijalističkom periodu" (vidi u ovom zborniku, sine pagina).

4 O tome ubedljivo govori Žarana Papić u tekstu "Od državnog socijalizma do državnog nacionalizma: slučaj Srbije iz rodne perspektive” (Žarana Papić, Tekstovi 1977-2002, uredile Adriana Zaharijević, Zorica Ivanović i Daša Duhaček, Beograd 2012): "Ukratko, glavni problem i najtragičniji rezultat dezintegracije bivše Jugoslavije je dominantan, manipulativan zahvat namernog izazivanja, konstruisanja i ,proizvodnje' nacionalizama i šovinizama - mitološki, narcisoidan, nerefleksivan, agresivan, ispunjen mržnjom prema drugim nacijama.”... "Nadalje, jedna od najvažnijih karakteristika svih ovih postkomunističkih demokratija jeste da njima dominiraju muškarci i da su one otvoreno patrijar- 
osvajala javni i privatni prostor postsocijalističke Srbije, ali i otpor "ugrožavanju prava stečenih u socijalizmu - pre svega reproduktivnih prava i prava na izbor, ali i drugih oblika jednakosti i socijalne zaštite". ${ }^{5}$

Devedesete godine u Srbiji obeležila su, stoga, dijalektička prožimanja feminističke teorije i prakse, za koja su svakako bile zaslužne feministkinje koje je ujedinjavala "svest o tome da rade na margini”. ${ }^{6}$ One su često istovremeno bile i aktivistkinje i naučnice, te je ova dva područja teško razdvojiti. Ipak, ne bi bilo preterano reći da je, barem kada je o teoriji reč, jedan od ključnih bastiona feminizma u Srbiji bio i ostao beogradski Centar za ženske studije, osnovan 1991. godine inicijativom organizacije "Žene i društvo”. Od samog početka, Centar je predstavljao mesto na kom se stiče neformalno, vaninstitucialno i interdisciplinarno obrazovanje, a "polazna pretpostavka u radu Centra za ženske studije, kao obrazovnog, prosvetiteljskog projekta bila [je] činjenica da nije bio vrednosno neutralan projekat - niti se tako ikada predstavljao - jer je njegova osnovna odrednica bila jasno političko opredeljenje protiv rata i nacionalizma, kao i utemeljenje u snažnoj feminističkoj aktivističkoj inicijativi... Osnivačice Centra za ženske studije i članice prvog Saveta Centra (1991/1992) bile su Marina Blagojević, Neda Božinović, Biljana Dojčinović Nešić, Sonja Drljević, Daša Duhaček, Jasmina Lukić, Lepa Mlađenović, Zorica Mršević, Žarana Papić, Slavica Stojanović i Jasmina Tešanovič”. ${ }^{7}$

Upravo u ovakvom, tek ovlaš skiciranom, društvenom kontekstu, i upravo u krilu Centra za ženske studije, u Srbiji se pojavljuje prvi “časopis za feminističku teoriju”, kako stoji u podnaslovu prvog broja Ženskih studija, objavljenog 1995. godine. Paralelno s njim, iste godine, u zimu 1994/1995, izlazi i prvi broj časopisa ProFemina časopisa za žensku književnost $i$ kulturu. Iako su u pitanju bila dva različita tipa časopisa i dva različita uređivačka tima (Ženske studije uređivale su Jasmina Lukić (1995-2000) i Branka Arsić (2000-2002), a ProFeminu Svetlana Slapšak, Radmila Lazić, Ljiljana Đurđić i Du-

\footnotetext{
halne, tradicionalne i konzervativne u pogledu statusa žena, njihove društvene uloge i značaja” (str. 295, 297).

5 Biljana Dojčinović, nav. delo, sine pagina. Ovo u više navrata ističe i Jasmina Lukić u već pomenutom tekstu: "Takva komparativna analiza omogućila bi takođe da se nasleđe socijalizma kritički redefiniše iz sadašnje perspektive kontinuirane degradacije svih oblika socijalnih prava, koja dobija svoje posebno rigidne oblike upravo u postsocijalističkim državama, u kojima se istovremeno briše sećanje na pozitivna iskustva života u socijalizmu" (str. 26).

6 Biljana Dojčinović, nav. delo, sine pagina.

7 http://www.zenskestudie.edu.rs/o-nama/istorija-centra (25. 9. 2017).
} 
bravka Đurić), njihove urednice su insisitrale na saradnji i jedinstvu, i oba časopisa su presudno obeležila rađanje feminističke (književne) teorije u Srbiji, što bismo, između ostalog, mogli da ilustrujemo i posluživši se rečima same Dubravke Đurić:

S jedne strane, u Ženskim studijama je postojala težnja da se, pre svega kroz prevedene, a tek sekundarno i kroz domaće autorske tekstove, postavi poststrukturalistička feministička paradigma. S druge strane, u studijama književnosti pokazuje se važnost rane angloameričke ginokritike, koja je postavljena kao dominantni pristup u proučavanju književnosti kako u Centru za ženske studije tako i u časopisu ProFemina. ${ }^{8}$

Iako u fokusu ovog istraživanja nije nijedan od pomenutih časopisa, i premda ono teži da ponudi pregled temata i prikaza objavljenih u časopisu Genero, ovakav ili sličan uvod čini se neophodnim. Naime, Genero nije časopis sui generis, već neposredni izdanak i nastavljač pomenutih Ženskih studija, koje su prestale da izlaze u tom obliku i pod tim imenom 2002. godine. Rečima Biljane Dojčinović i njene zamenice Jelisavete Blagojević, koje su uređivale ovaj časopis u periodu od 2002. do 2007. godine (zaključno sa brojem 8/9): "Genero je novo ime časopisa za feminističku teoriju Ženske studije. [...] Po svojoj sadržini, Genero sledi koncept koji su Ženske studije gradile od samog početka, kao sastavni deo projekta Centra za ženske studije”. To znači da, premda se život ovog časopisa odvija u znatno izmenjenim istorijskim okolonostima (on počinje da izlazi čitavu deceniju nakon osnivanja Centra, u postpetooktobarskoj Srbiji, nakon iskustva ratova i sankcija), njegova ukorenjenost u tradiciji Centra za ženske studije na kojoj novo uredništvo insistira podrazumeva očuvanje aktivističke, antiratne i antinacionalističke inicijative, udruženih sa osnovnim (široko postavljenim, ali jasnim) ciljem njegove preteče, časopisa Ženske studije:

Feminizam - ili, bolje, feminizmi - pojam je koji ne upućuje na konsenzus, već na mnoštvo često međusobno različitih pravaca i pristupâ osnovnom problemu, a to je podređeni položaj žene u datim socijalnim konstelacijama i simbolička predstava o njoj kao o Drugom. Potreba da se ta razlika učini vidljivom, i da se artikulišu njene pretpostavke i implikacije, jedno je od

8 Dubravka Đurić, "Feministički i ženski časopisi u postjugoslovenskim kulturama”, ProFemina, specijalni broj, leto-jesen 2011, str. 273. 
temeljnih polazišta feminističke teorije u najširem smislu, i biće tematska okosnica časopisa koji pokrećemo. Prihvatajući feminizam kao svoje osnovno polazište, redakcija ne želi da se opredeljuje za bilo koji od postojećih pravaca unutar same feminističke misli. Deo našeg zadatka biće da ponudimo mogućnost prepoznavanja i artikulacije razlika ne samo u odnosu na tradicionalna shvatanja u pojedinim oblastima, već i među feminizmima. ${ }^{9}$

Promene do kojih dolazi sa novim uredništvom ipak se nisu iscrpele preimenovanjem časopisa. Između ostalog, sada se mnogo više insistira na objavljivanju tekstova "domaćih i autora/autorki iz regiona. [...] Genero je zainteresovan da postane forum na kom se može raspravljati o različitim problemima teorije roda u regionu." 10

Istorija Genera nije sasvim jednolična i pravolinijska. Zbog nedostatka finansijskih sredstava, časopis nije izlazio u periodu od 2008. do 2011. godine.

Centar za ženske studije krajem 2010. godine donosi odluku o ponovnom objavljivanju Genera, sa novim uredništvom i podnaslovom časopisa. Tokom 2011. godine Centar je objavio zaostala četiri broja $(12 / 2008,13 / 2009,14 / 2010$ i 15/2011) i na taj način je uspostavljen kontinuitet časopisa. Genero: časopis za feminističku teoriju i studije kulture izlazi jednom godišnje i objavljuje naučne članke iz oblasti feminističke teorije i studija roda, kao i iz nauke, kulture i teorije umetnosti sa naglaskom na interdisciplinarnom i kritičkom pristupu. U Generu objavljuju domaće/i i strane/i autorke i autori na bhs i engleskom jeziku. ${ }^{11}$

Nova urednica časopisa je Daša Duhaček, a njena zamenica Katarina Lončarević. Promena uredništva tek donekle je dovela i do promene uređivačke politike časopisa, što je uočljivo već i iz same promene podnaslova, ali osnovni ciljevi, postavljeni godinama ranije, ostaju isti.

9 "Reč uredništva", Ženske studije br. 1, nav. prema http://zenskestudie.edu.rs/ izdavastvo/elektronska-izdanja/casopis-zenske-studije/zenske-studije-br-1/276rec-urednistva (25. 9. 2017), naglasila autorka.

10 "Reč uredništva", Genero br. 1, nav. prema http://zenskestudie.edu.rs/izdavastvo/ casopis-genero/16-genero-casopis-za-feministicku-teoriju-i-studije-kulture (25. 9. 2017).

11 Isto. 


\section{STRUKTURA ČASOPISA "GENERO: ČASOPIS \\ ZA FEMINISTIČKU TEORIJU" (2002-2007)}

Za prvu fazu izlaženja časopisa Genero karakteristična je tematska određenost skoro svakog broja ili dvobroja. U ovom periodu u časopisu su se smjenjivale sljedeće teme: američka feministička kritika (broj 1), politike pola (2/3), žene, nauka, obrazovanje i životna sredina (tema broja I) i politike "prevođenja" feminističkih teorija (tema broja II) (4/5), američka feministička kritika, III dio (6/7), razlike, seksualnosti, kon/teksti (8/9), kako do odgovornosti (10/11).

U prvom broju Genera objavljena su dva originalna naučna rada, jedan pregledni članak i jedan stručni članak. U okviru teme broja dominantni su prevodi, tačnije, tu je pet prevoda i jedan pregledni članak, a dva prevoda su prisutna i u rubrici "Iz regiona”. Rubrika "Prikazi” sadrži jedan prikaz. Dvobroj 2/3 donosi ukupno deset prevoda (jedan u vidu uvodne beleške, sedam u okviru temata i dva u rubrici "Iz regiona"), tri prikaza i dva originalna naučna rada. Posebno izdanje časopisa Genero izlazi 2004. godine. U njemu su predstavljena istraživanja mehanizama funkcionisanja medijskih sadržaja i medijske publike koja su sprovele studentkinje Centra za ženske studije u periodu između 2001. i 2002. godine. ${ }^{12} \mathrm{U}$ ovom broju objavljeni su studentski istraživački radovi, istraživački intervjui, diskusija na temu fragmenata iz razgovora fokus grupe, tri prevoda naučnih radova i jedan originalni naučni rad. U izdanju 4/5 objavljen je jedan pregledni članak i šest originalnih naučnih radova, kao i devet prevoda, od čega je jedan prevedeni intervju u posebnoj rubrici ovog izdanja naslova In memoriam Žak Derida. Pored ovoga, prisutna su i tri prikaza. Dvobroj 8/9 iz 2006. sadrži sedam originalnih naučnih radova, jedan esej, jedan intervju, tri prevoda i pet prikaza. Naredne godine izlazi prvo i do sada jedino elektronsko izdanje časopisa koje donosi prevode, esej i jednu kratku priču. U dvobroju 10/11 objavljeno je devet originalnih naučnih radova, jedan stručni rad i četiri prikaza.

Prema navedenim podacima, u Generu je u periodu od 2002. do 2007. godine objavljeno najviše prevoda, ukupno 32 teksta.

\section{STRUKTURA ČASOPISA "GENERO: ČASOPIS ZA FEMINISTIČKU TEORIJU I STUDIJE KULTURE" (2008-)}

Časopis Genero od 2008. godine prestaje da bude tematski orijentisan, pa tako temu broja ili temat imaju samo tri izdanja od devet. U

12 Snježana Milivojević, “Žene i mediji: strategije isključivanja”, Genero, posebno izdanje, 2004, str. 9. 
izdanjima 12 i 17 ponavlja se istovjetni temat naslova Politike rodne ravnopravnosti, dok je u 13. broju temat Rod, identitet i turbo folk kultura.

U časopisu su načelno najprisutniji naučni radovi, studije, ogledi i prikazi, sa izrazito manjim brojem prevoda. U broju 12 iz 2008. godine objavljeno je 8 originalnih naučnih radova i 2 prikaza. Broj 13 sadrži 8 naučnih radova, 4 prikaza i jedan prevod. U broju $14 \mathrm{u}$ rubrici "Studije i ogledi" objavljeno je 7 naučnih radova, pored kojih su predstavljena i 4 prikaza i 1 prevod. "Studije i ogledi" broja 15 sadrže 9 naučnih radova, "Prikazi” sadrže 4 prikaza, a u broju se nalazi i rubrika "Prevod", sa jednim prevedenim tekstom. U broju 16 objavljeno je 9 naučnih radova u okviru rubrike "Studije i članci", zatim 6 prikaza i rubrika "In memoriam", sa dva teksta posvećena Adrijen Rič i Šulamit Fajerston. U broju 17, u okviru temata Politike rodne ravnopravnosti predstavljeno je 6 naučnih radova, a u rubrici "Studije i članci" predstavljena su 4, dok rubrika "Prikazi" broji 5 tekstova. Broj 18 donosi 8 naučnih radova i 4 prikaza, dok je u broju 19 objavljeno 8 naučnih radova, 4 prikaza i rubrika "In memoriam", sa jednim tekstom posvećenim Oliveri Milosavljević. Posljednji broj časopisa uzet u obzir u ovom radu jeste iz 2016. godine i sadrži 7 originalnih naučnih radova i 3 prikaza. Prema ovim podacima, u časopisu Genero: časopis za feminističku teoriju i studije kulture u periodu od 2008. do 2016. godine objavljena su ukupno 74 naučna rada, 32 prikaza i svega 3 prevoda.

\section{TEMAT "AMERIČKA FEMINISTIČKA KRITIKA" U PRVOM BROJU "GENERA"}

U prvom broju časopisa Genero objavljen je temat Američka feministička kritika u kojem su predstavljeni tekstovi američkih feministkinja: Džudit Feterli (Judith Fetterley), Anet Kolodni (Annette Kolodny), Majre Dželen (Myra Jehlen), Lilijan S. Robinson (Lilian S. Robinson) i Rejčel Blau DuPlezi (Rachel Blau DuPlessis), kao i uvod $\mathrm{u}$ temat u vidu preglednog članka pod nazivom "Feministička čitanja i preispitivanje književnog kanona”, u kom urednica Biljana Dojčinović daje sintezu pet odabranih eseja pomenutih autorki, značajnih za feministička čitanja i preispitivanja književnog kanona. Urednica predstavlja radove u kojima se preispituju protofeminističke metode čitanja, interpretiranja i predavanja književnosti, te predlažu novi pristupi, proistekli iz feminističke kritike. Feminističko preispitivanje izvršeno u ovim esejima predstavlja dekonstrukciju nasljeđa zapadne 
humanističke kulture, utemeljene na dominantnoj muškoj ideologiji koja pojam univerzalnog izjednačava sa muškim, što rezultira isključivanjem i ograničavanjem ženskog polja djelovanja u oblasti kulture i književnosti i konstrukcijom ženskog identiteta u skladu sa standardima dominantne tradicije. U predstavljenim tekstovima posmatraju se svi pomenuti aspekti, uz neminovno razmatranje samog književnog kanona i problema njegove vrijednosti.

Prvi tekst temata jeste uvod u knjigu Čitateljka koja pruža otpor: feministički pristup američkoj fikciji Džudit Feterli, koja je objavljena 1978. godine. U uvodnom poglavlju naslovljenom "O političkoj prirodi književnosti” autorka iznosi osnovne ideje o poziciji ženskog stvaralaštva u okviru književnog kanona, dovodeći u pitanje pojam univerzalnosti. Autorka smatra da književni kanon insistira na univerzalnosti, a univerzalnost pritom definiše isključivo muškim terminima. ${ }^{13}$ Predočeni problem je direktna posljedica onoga što autorka definiše "politikom književnosti" u kojoj je, po logici stvari, pitanje moći pitanje od fundamentalnog značaja. Džudit Feterli smatra da u književnosti nije u dovoljnoj mjeri zastupljeno autentično žensko iskustvo, a ono koje se tako određuje predstavlja konstruisanu sliku uobličenu prema opšteprihvaćenim društvenim normama i stereotipima. Otuda proizlazi i njen stav o isključenosti žena iz književnosti. Tvrdnje koje iznosi autorka ilustruje na sistematičan način na korpusu sačinjenom od četiri priče i četiri romana ${ }^{14} \mathrm{u}$ kojima istražuje stereotipne i mizogine predstave o ženama sačuvane u reprezentativnim djelima američke književnosti. Ovaj esej Džudit Feterli pruža značajan uvid u neistražene mehanizme preko kojih se mizogine predstave oblikuju i interpoliraju u kolektivnu svijest, te ukazuje na potrebu revizije književnosti pomoću koje bi se "privelo u svijest ono što je u velikoj mjeri ostalo nesvjesno". ${ }^{15}$

Sljedeći je esej Anet Kolodni "Mapa ponovnog čitanja: rod i interpretacija književnih tekstova”, objavljen 1980. godine. U ovom eseju Kolodni polazi od teorije uticaja Harolda Bluma koju smatra

13 Džudit Feterli, “O političkoj prirodi književnosti”, Genero, br. 1, str 47.

14 Korpus koji je Džudit Feterli odabrala sačinjavaju priče "Rip Van Vinkl” Irvina Vošingtona (Irving Washington), "Želim da znam zašto" Šervuda Andersona (Sherwood Anderson), "Beleg” Natanijela Hotorna (Nathaniel Hawthorne) i "Ruža za Emili” Vilijema Foknera (William Faulkner), zajedno sa romanima Zbogom oružje Ernesta Hemingveja (Ernest Hamingway), Veliki Getsbi Frensisa Skota Ficdžeralda (Francis Scott Fitzgerald), Bostonjanke Henrija Džejmsa (Henry James) i Američki san Normana Mejlera (Norman Mailer).

15 Džudit Feterli, nav. delo, str. 46. 
maskulinocentričnom, ${ }^{16}$ jer se stvaralački uticaj na kome je utemeljena prenosi i poprima u okviru univerzalnog, tradicionalno muškog kanona, o kojem je pisala i Džudit Feterli. Dok Blum smatra da postoji književna tradicija kojoj svi pripadamo i u skladu sa kojom su formirane naše interpretativne strategije, Kolodni smatra da su takvi interpretativni pristupi nepotpuni, jer ne uzimaju u obzir dimenziju roda koji u mnogočemu oblikuje naše viđenje i shvatanje književnog djela. Autorka svoje stanovište poktrepljuje istraživanjem interpretativnih strategija u pričama "Žuti tapet" Šarlot Perkins Gilmen (Charlotte Perkins Gilman) i "Porota njoj jednakih" Suzan Kiting Glaspel (Susan Keating Glaspell), preko kojih pokazuje suprotstavljenost muškog i ženskog shvatanja simboličkih predstava. Autorka zastupa tezu da različiti sistemi vrijednosti kojima se žene i muškarci vode uzrokuju različita tumačenja simboličkog jezika, te da su "ženska značenja nepristupačna muškoj interpretaciji". ${ }^{17} \mathrm{~S}$ druge strane, žene su u stanju da razumiju muški sistem značenja, što Kolodni objašnjava argumentom bliskim postkolonijalnoj i kolonijalnoj kritici prema kojem "potlačene ili pokorene grupe uvek proučavaju značenja i gestove onih koji ih kontrolišu", ${ }^{18} \mathrm{u}$ ovom slučaju muškaraca koji kontrolišu javni diskurs.

Anet Kolodni se zalaže za usvajanje interpretativnih pristupa koji bi u obzir uzimali rod, ali i druge faktore, poput rase i klasne pripadnosti. Poput Džudit Feterli, i ona predlaže revizionističko čitanje kojim bi se osvijetlila polja književne istorije čije su nositeljke žene i kojim bi se "izmenila naša iskrivljena percepcija”. Prema riječima autorke, ženska književnost zahtjeva razvijanje posebnih interpretativnih umijeća, a oni koji je tumače, kako žene tako i muškarci, treba da je čitaju "u okviru sopstvenih jedinstvenih i poučnih konteksta značenja i simbola". ${ }^{19}$

Majra Dželen u eseju iz 1981. godine "Arhimed i paradoks feminističke kritike" metaforizuje problem pozicioniranja feminističke kritike, koja problem ideološke oprečnosti sa prevalentno maskulinističkim standardima u tradicionalnom književnom diskursu prevazilazi stvaranjem "alternativnog konteksta, svojevrsne ženske enklave

16 Biljana Dojčinović, "Feministička čitanja i preispitivanje književnog kanona", Genero, br. 1, 2002, str. 37 .

17 Anet Kolodni, "Mapa ponovnog čitanja: rod i interpretacija književnih tekstova", Genero, br. 1, 2002, str. 69.

18 Anet Kolodni, nav. delo, str. 69.

19 Isto, str. 71. 
odvojene od univerzuma maskulinističkih postavki”. ${ }^{20}$ Dželen analizira status ženskih autora $\mathrm{u}$ književnosti na primjeru sentimentalnih romana iz 19. vijeka, diskutujući prije svega teze američke teoretičarke Nine Bejm (Nina Baym). Nadovezujući se na neke od tih teza, autorka artikuliše pitanje kontradiktornosti sentimentalnih romana koja se ogleda u tome što komercijalni uspjeh njihovih autorki istovremeno označava i njihov neuspjeh na književno-umjetničkom planu. Sentimentalni pravac stoga ne treba da bude sredstvo ženske književne emancipacije jer takva emancipacija, prema mišljenju autorke, ne podrazumijeva prevazilaženje već eksploatisanje sopstvene nemoći. Ipak, ona smatra da takva dela ne treba odbaciti, već interpretirati u skladu sa načelima feminističke kritike, a potom konfrontirati sa procjenama tradicionalne kritike. U osnovi njene misli jeste poređenje muškog i ženskog viđenja, u cilju iznalaženja tačke u kojoj se prepliću definicija žene i definicija svijeta. ${ }^{21}$

Esej "Izdaja našeg teksta: feministički izazovi književnom kanonu” Lilijan S. Robinson objavljen je 1983. godine. U njemu se preispituje pozicija ženske književnosti u okviru književnog kanona koji autorka vidi kao "džentlmenski dogovor", odnosno, dogovor "pripadnika povlašćene klase i muškog roda". ${ }^{22}$ Ona smatra da je jedan od glavnih zadataka feminističke kritike procjenjivanje i objavljivanje djela zanemarenih i potcjenjenih autorki, te umetanje ženske perspektive, pisane jezikom žena, u već ustanovljeni kanon. Autorka smatra da u ovom procesu konačni rezultat može da bude stvaranje ženskog "protiv-kanona”, što može dovesti do dodatne izolacije i marginalizacije ženskog stvaralaštva. S druge strane, vrednovanja književnih djela često su zasnovana na jednoobraznim kriterijumima po kojima se izuzetnost veže za tipično muške vrijednosti, ${ }^{23}$ što implicira da je potencijalni modalitet nepristrasne procjene vrijednosti ženskog stvaralaštva restrukturizacija i revizija samog književnog kanona. U tom smislu, Lilijan Robinson postavlja značajno pitanje retoričkog karaktera:

20 Majra Dželen, “Arhimed i paradoks feminističke kritike”, Genero, br. 1, 2002, str. 74 .

21 Isto, str. 83.

22 Lilijan S. Robinson, "Izdaja našeg teksta: feministički izazovi književnom kanonu”, Genero, br. 1, 2002, str. 98.

23 Ovdje autorka citira Ninu Bejm koja u uvodu studije o američkoj ženskoj pripovednoj prozi između 1820. i 1870. godine piše o pristrasnim kriterijumima primjenjivanim u procjeni najboljih djela američke književnosti, navodeći kao primjer činjenicu da je prilikom određivanja simbola ljudske zajednice prednost davana brodu koji je išao u lov na kitove a ne skupini žena koje su se okupljale i zajedno šile (Baym, 1978, nav. prema: Robinson, 1983, str. 103). 
Treba da shvatimo da li tvrdnja glasi da mnogi od nedavno otkrivenih i vrednovanih tekstova, koje su napisale žene, odgovaraju postojećim kriterijumima ili, sa druge strane, da li ti kriterijumi sami po sebi suštinski isključuju ili naginju isključivanju žena i stoga treba da budu modifikovani ili zamenjeni. ${ }^{24}$

Posljednji esej u tematu pod naslovom "Etrurkama" autorke Rejčel Blau DuPlezi znatno se razlikuje od prethodna četiri eseja po formi i stilu. Radi se o veoma specifičnom doprinosu feminističkoj kritici uobličenom iz bilješki i pisama, ${ }^{25}$ što se jasno vidi po tekstualnim strukturama prepunim unutrašnjih monologa, nedovršenih rečeničnih fragmenata, autobiografskih nota, uzvičnika i ličnih opaski čija upotreba evocira direktno zapisivanje misli i asocijacija, karakteristično za roman toka svijesti. Književni postupci kojim se gradi esej ne utiču na zamagljivanje njegove suštinske funkcije kritičkog teksta u kojem su predstavljena načela ženskog pisanja i ženske estetike. Ženska estetika je predočena kao mjesto sjedinjenja ili pak produbljenja kontradikcija, ukidanja hijerarhija i spajanja različitih svijesti, tačnije, pluralizma koji se kontrapozicionira jednoj jedinoj "ženskoj estetici" i, u okviru nje, jednoj jedinoj "konstelaciji strategija”. ${ }^{26}$ Pristup književnom stvaralaštvu se analizira i iz perspektive roda, te se sugeriše da muškarci teže normiranom, kanonizovanom stilu, dok ženski stil više odlikuje apstraktnost, emocionalnost i neuklapanje u šablon, što se dalje ilustruje preko reference na Doris Lesing (Doris Lessing):

On: toranj, jeste nihilizam, ambis, rigidnost, izolacija i kontrola; jeste hrabrost, razum i bolest. Ona: list, oblik vulve. Ona je prožeta iracionalnom srećom, čulnošću, užitkom i otvorenošću prema zajednici. Krasi je zdravi razum, ne dovodi filozofske pozicije do krajnosti i ne vezuje se za njih. Ovo žensko gledanje na jednoj je strani polariteta (“ženstvenoj strani”) pa ipak je i snaga koja uključuje i transcendira muški nihilizam i racionalnost. ${ }^{27}$

24 Lilijan S. Robinson, nav. delo, str. 103.

25 Autorka u fusnoti koja se odnosi na sam naslov eseja iskazuje zahvalnost ženama koje su joj pružile pisma i bilješke na osnovu kojih je oblikovala svoj rad, i napominje da joj je kao izvor inspiracije u pisanju poslužila Knjiga o H.D. Roberta Dankana (Robert Duncan).

26 Rejčel Blau DuPlezi, "Etrurkama”, Genero, br 1, 2002, str. 114.

27 Doris Lesing, 1958, nav. prema: Rejčel Blau DuPlezi, nav. delo, str. 117. 
Izdvojena misao, prema viđenju autorke, "sadrži ženskost, transcendira muškost (i) potvrđuje da je žensko sinteza" ${ }^{28}$

Jedan od prioriteta časopisa Genero bilo je objavljivanje prevoda tekstova iz američke feminističke kritike, čime je napravljen veliki pomak u upoznavanju i širenju feminističkih pogleda u ovdašnjoj akademskoj i vanakademskoj sferi. Prema tome, priređeni prevodi predstavljaju rezultat težnje da se feminističke teorijske postavke učine dostupnim našoj javnosti, da bi se potom mogle sagledati i tumačiti u okvirima domaćeg konteksta. Temat o američkoj feminističkoj kritici pronalazi svoje mjesto već u prvom broju časopisa, što upućuje na to da je našoj feminističkoj teoriji u tom periodu nedostajao uvid u neke od fundamentalnih koncepata koji su u Sjedinjenjim Američkim Državama predstavljeni još prije deceniju ili dvije, te da Genero namerava da, koliko je to moguće, popuni te teorijske praznine i postane izvor diseminacije ovih pojmova. O značaju širenja zapadnih feminističkih ideja svjedoči i ponavljanje istovjetnog temata Američka feministička kritika, III dio u dvobroju 6/7 iz 2005. godine. Oba ova temata predstavljaju nastavak projekta započetog još u časopisu Ženske studije, u kojem je 1996. godine objavljen prvi temat o američkoj feminističkoj književnoj kritici. Predstavljeni u različitim vremenskim periodima, ova tri temata se međusobno nadovezuju i sjedinjuju u zajedničkom cilju da se na osnovu teorijskog znanja koje je u njima predstavljeno sačini čitanka za kurseve iz književnosti na ženskim studijama i na taj način doprinese legitimizaciji feminističkog znanja.

Kada je riječ o kriterijumima odabira temata i eseja za prvi broj časopisa, može se reći da se oni poklapaju sa već iskazanim težnjama i ciljevima, koji su opšte mjesto u feminističkoj borbi. O ovome svjedoče i riječi tadašnje urednice Genera, koja na ovu temu kaže sljedeće:

[...] reč je o klasičnim tekstovima koji su uglavnom pokrenuli brojne reakcije i nova promišljanja na ove teme. Otud se bez njihovog poznavanja ne mogu razumeti ni kasnija kretanja u ovom pristupu, i može se reći da je njihovo prevođenje, iako sa zakašnjenjem, i sada veoma značajno. Za razliku od teorijske strane, veoma su važna i praktična pitanja koja oni otvaraju, naročito s obzirom na ovdašnje okolnosti. ${ }^{29}$

28 Isto.

29 Biljana Dojčinović, “Feministička čitanja...”, str. 39. 


\section{MESTO GEN(D)ER-ACIJSKIH SUSRETA: RUBRIKA "PRIKAZI" U ČASOPISU "GENERO" (2002-2016)}

Na samom početku, neophodno je istaći da je u pitanju stalna rubrika - ne nailazimo ni na jedan od dvadeset brojeva časopisa Genero u kom nema makar jednog prikaza. Za razliku od prvog broja, u kojem je objavljen samo jedan prikaz (pohvalni tekst Dubravke Đurić o knjizi Ženske ikone $X X$ veka Svetlane Slapšak),,$^{30}$ sa narednim brojevima i prikazi postaju brojniji. Tako je do sada ukupno objavljeno pedeset osam tekstova u rubrici "Prikazi", te bi se moglo zaključiti da ih u proseku ima tri po jednom broju. Kao i inače, i u ovom časopisu pozicija prikaza je unekoliko marginalna. Budući da su u pitanju eksplicitni, sažeti komentari na primarni tekst (bila to naučna studija ili fikcionalno delo), prikazi se najčešće doživljavaju kao tekstovi od sekundarnog značaja. O tome svedoči čak i njihovo smeštanje na završne strane časopisa. Prikazi su svojevrsni "dodatak" glavnini časopisa koju sačinjavaju autorski tekstovi stranih i domaćih autora koji se objavljuju/prevode na maternji jezik prvi put. Ipak, insistiranje oba uredništva Genera na kontinuiranom objavljivanju prikaza nesmanjenim intenzitetom svedoči o prepoznavanju i isticanju značaja koji ova forma ima za časopis, a time i za njegove čitaoce. Pored toga, opšti sud o marginalnosti prikaza lako se može dovesti u pitanje - pisanje prikaza, baš kao i pisanje autorskog članka, takođe može biti stvaralački proces, i na to uvek iznova treba skretati pažnju. Svako kritičko čitanje je po sebi kreativno, te nema razloga da se ovo svojstvo porekne njegovom pisanom uobličenju.

U slučaju časopisa Genero, odrednica "prikaz” obuhvata kritičke komentare i preglede tekstova različitih žanrova: u pitanju su teorijski tekstovi - naučni članci ili čitave studije, zbirke eseja, zbornici, temati časopisa, objavljena statistička istraživanja i drugo, s jedne strane, kao i pesnička i prozna književna dela napisana na srpskom i na stranim jezicima, s druge. Kada je reč o umetničkim ostvarenjima, književnost nesumnjivo ima povlašćenu, čak ekskluzivnu poziciju. Kao posebno polje mogli bismo razmatrati prikaze radova objavljenih u regionu, budući da same urednice od 2002. godine do danas eksplicitno govore o porivu da u rad časopisa uključe i regionalne autor(k)e, kao i da posvete pažnju njihovoj produkciji. ${ }^{31}$

30 Ova činjenica je više nego interesantna, budući da je u pitanju svojevrsni susret dveju urednica časopisa ProFemina na stranicama prvog broja časopisa koji je nasledio Ženske studije, što svedoči o kontinuiranoj stručnoj saradnji i međusobnoj podršci između naučnica i aktivistkinja koje stoje iza ovih časopisa.

31 http://zenskestudie.edu.rs/izdavastvo/casopis-genero/16-genero-casopis-za-feministicku-teoriju-i-studije-kulture (25. 9. 2017). 
U periodu od 2002. do 2007. godine objavljen je dvadeset jedan prikaz: veći deo, njih trinaest, odnose se na teorijske eseje/studije i stručne publikacije (̌̌est na one napisane na srpskom, a sedam na one napisane na stranom jeziku). Čak osam prikaza ujedno su i svojevrsni književnokritički ogledi. Jedan od njih bavi se domaćom produkcijom (tekst "Srce i kažiprst moj mali su pribor za čitanje" Nede Radulović o pesničkoj zbirci Pribor za čitanje Olivere Vuksanović), dok je preostalih sedam posvećeno stranoj književnosti. U pitanju su sledeći tekstovi: Ana Kolarić i Neda Radulović, "Kosti govore” (Čendžerai Hove, Kosti, prevela Nadežda Obradović, biblioteka Gral, CLIO, Beograd, 2003); Saša Sojkić, "Neizvesna svetlost” (Baha Tahir, Svetla tačka, prevela Dragana Đorđević, CLIO, Beograd, 2003); Biljana Dojčinović Nešić, "Svila za Vanesu" (Hong Ying, K. Umeće ljubavi, preveli Jin Xiaolei i Radosav Pušić, Plato, Beograd 2005); Ivana Prentović-Krivokapić, "Poslednji meseci Silvije Plat" (Kejt Mouzis, Zima Silvije Plat, prevela Tanja Slavnić, Agora, 2005); Ivana Prentović-Krivokapić, "Zabeleške o opsesiji” (Zoi Heler, Zabeleške o skandalu, prevela Maja Kaluđerović, Laguna, 2005); Hana Ćopić, “Čitač” - (Bernhard Šlink, Čitač, prevela Spomenka Krajčević, Plato, Beograd, 2002) i Katarina Lončarević, "Ćutanje, sramota i istina” (Ginter Gras, Ljušteći luk, preveo Zoran S. Cvetković, Narodna knjiga - Alfa, 2007)..$^{32}$ Izuzev poslednjeg među njima, koji predstavlja kritičko čitanje memoarske proze s fokusom na lik i delo autora kao prevashodno političke, a tek potom književne figure, ostali prikazi uglavnom su sažeti književnokritički ogledi čiji je primarni cilj da opišu i istaknu estetske kvalitete savremenih ostvarenja, a uporedo s tim i relevantnost problema koje ova dela tematizuju, a tek sekundarni da naslute njihov potonji književnoistorijski značaj. ${ }^{33}$

32 Poslednja dva prikaza objavljena su u broju 10/11, čiji je temat "Kako do odgovornosti" uredila Daša Duhaček, te su i prikazane knjige odabrane u skladu sa tim; osnovna intencija autorki bila je da problematizuju njihovu tematiku, a ne književnu vrednost.

33 Stiče se utisak da su ovi tekstovi mnogo bliži tzv. "novinskoj” nego "naučnoj" književnoj kritici, onako kako ove pojmove definiše Rečnik književnih termina (ur. Dragiša Živković, Nolit, Beograd 1992): “Dok je novinska kritika savremenih književnih dela fokusirana na 'ocjenjivanju, dijeleći, u pravilu, grubim mjerilima posve neuspjela književna djela od onih koja su, po mišljenju kritike, vrijedna pažnje čitalaca', književni kritičar sa naučnim pretenzijama posmatra dela iz prošlosti sa distance, sa znanjem iz književne istorije koje mu omogućava da razmatra zašto su neka dela preživela (citirano prema: Ana Kolarić, "(Raz)govor o književnosti i feminizmu: rane kritike Rebeke Vest”, Knjiženstvo, časopis za studije književnosti, roda i kulture, godina IV, broj 4), http://www.knjizenstvo. rs/magazine.php?text=132 (25. 9. 2017). Ipak, treba naglasiti da su, kao i inače, i u slučaju Genera ove granice nedovoljno oštre i očigledne, i da zavise od stručnosti, afiniteta i ambicija autorki/autora koji potpisuju prikaze. 
Gotovo uvek reč je o romanima, ali ne ekskluzivno, kako bi se moglo očekivati, o onima koje su napisale žene - naprotiv, zastupljenost autorki i autora gotovo da je podjednaka. ${ }^{34}$ Kada je, pak, reč o autorima i autorkama samih prikaza, situacija je drugačija - sa izuzetkom prikaza Saše Sojkića, sve ostale potpisuju žene.

U periodu od 2008. do 2016. dolazi do promena na koje nam ukazuje statistika - od ukupno trideset sedam prikaza, čak trideset četiri predstavlja kritičke osvrte na teorijske tekstove, a tek tri na književna dela. Zanimljivo je da sva tri potpisuje ista autorka, koja je svoja sažeta (prevashodno deskriptivna) razmatranja recentno objavljenih ili prevedenih dela objavljivala i do tada - Ivana Prentović Krivokapić. U pitanju su tekstovi "Osveta zaboravljene heroine" (Žil Leroa, Alabama song, Paideia, Beograd, 2008), "Priče o ljubavi, priče o patnji” (Brižit Žiro, Ljubav je precenjena, Stylos Art, Novi Sad, 2009) i "Tragična metamorfoza jedne žene" (Kejt Šopen, Buđenje, Službeni glasnik, Beograd, 2011). Posle 2012. godine, počev od sedamnaestog broja, u Generu ne nailazimo ni na jedan prikaz ovakve vrste. Štaviše, na to ukazuju i najave potonjih brojeva, budući da se ova rubrika definiše kao ona u kojoj su zastupljeni "prikazi najnovije naučne i stručne literature". ${ }^{35}$

Ova disproporcionalnost u vezi je sa promenom uredništva Genera. U doba kada časopis uređuje Biljana Dojčinović, književna kritičarka i teoretičarka, veliki deo tekstova i čitava dva temata časopisa (broj 1 i broj 6/7) posvećeni su upravo književnokritičkim i književnoteorijskim pitanjima. Genero u izvesnom smislu figurira, između ostalog, i kao prostor na kom se promoviše i artikuliše feministička književna kritika u najširem smislu, s posebnim fokusom na angloameričku ginokritiku. ${ }^{36}$ To ne znači da je posle 2007. godine Genero

34 Međutim, u svakom prikazu je reč o književnim delima koja, čak i ako ih nisu napisale žene, na različite načine problematizuju poziciju žene kao Drugog, te su stoga u skladu sa načelnom uređivačkom politikom časopisa. U tom smislu, korisno je podsećanje na reči Toril Moi koja "najpre ukazuje na jedno od središnjih načela feminističke kritike - 'nijedan prikaz ne može biti neutralan', a potom ističe da je glavni cilj feminističke kritike uvek bio politički - 'ona teži razotkriti, a ne ovekovječiti patrijarhalne prakse', citirano prema: Ana Kolarić, nav. delo.

35 Tako stoji u najavi 18, 19. i 20. broja. Najave su dostupne na sajtu Centra za ženske studije.

36 Jednu od najčuvenijih i najuticijanijih podela feminističke kritike u širem smislu čini Ilejn Šouvolter, razlikujući feminističku kritiku u užem smislu i ginokritiku. Sličnu podelu iznosi i Toril Moi govoreći o dve faze feminističke kritike u Americi. Dok prvu karakteriše iščitavanje dela (često kanonskih) muških i ženskih autora u kojima se prepoznaju postupci stereotipizacije ženskih likova i različiti vidovi njihove diskriminacije koji se očituju u književnosti, druga je usmerena na žene- 
to prestao da bude. Naprotiv, i u narednim brojevima sporadično su se pojavljivali autorski tekstovi iz ove oblasti (možemo izdvojiti, na primer, tekst Nađe Bobičić "Modernističke odlike u Fỉlozofskim fragmentima i esejima Ksenije Atanasijević" iz osamnaestog, odnosno Jasmine Radojičić "Živanine cipele: patrijarhat, mizoginija, i nacionalizam u romanu Knjiga o Milutinu Danka Popovića”, iz devetnaestog broja časopisa), kao i prikazi naučnih studija posvećenih književnosti. Ipak, jasno je da je došlo do promena i da je književnokritičkih ogleda bilo sve manje. Po odlasku Biljane Dojčinović, rubrika "Prikazi" u časopisu Genero donekle prestaje da bude platforma na kojoj (često mlade i još uvek ne sasvim profilisane) književne kritičarke i teoretičarke objavljuju svoje interpretativne oglede. Tu mogućnost s vremenom otvara časopis Knjiženstvo, sastavni deo projekta "Knjiženstvo: teorija i istorija ženske književnosti na srpskom jeziku do 1925. godine", čije je glavna urednica upravo Biljana Dojčinović. ${ }^{37}$

S druge strane, čini se da se od 2008. godine u Generu veća pažnja posvećuje publikacijama objavljenim u regionu, to jest gotovo isključivo u Hrvatskoj, barem kada su u pitanju prikazi naučnih studija. U tom kontekstu mogu se izdvojiti dva teksta Dubravke Đurić: "Konstrukcija pamćenja i sistemi reprezentacije" (Renata Jambrešić Kirin, Dom i svijet - O ženskoj kulturi pamćenja, Centar za ženske studije, Zagreb, 2008) i "Ginokritička interpretacija poezije" (Darija Žilić, Pisati mlijekom - Ogledi o poeziji savremenih autorica, Zagreb, AltaGama, 2008), ali i tekstovi "Od prvih početaka do uvoda" Jovane Đurović (Lada Čale Feldman i Ana Tomljenović, Uvod u feminističku književnu kritiku, Leykam International, Zagreb, 2012) i "Feminističko čitanje stvarnosti” Nađe Bobičić (Đurđa Knežević, Feminizam i kako ga steći, Fraktura, Zagreb, 2012). Na ovom mestu treba istaći i prikaz autorke iz Hrvatske Lade Čale Feldman posvećen knjizi Biljane Dojčinović Susreti u tami: uvod u čitanje Virdžinije Vulf.

Pored toga, posle 2007. godine upadljiv je porast zastupljenosti stručnih publikacija domaćih autorki i, u retkim slučajevima, autora (dvadesetak prikaza posvećeno je savremenim teorijskim promišljanjima i naučnim studijama objavljenim u Srbiji, oko pet prikaza onim objavljenim u regionu, dok se desetak tekstova odnosi na strane publi-

autorke, odnosno, na rekonstruisanje i priznavanje tradicije književnosti koju pišu žene. U fokusu prvog pristupa je "žena kao ona koja čita”, u fokusu drugog “žena kao ona koja piše”. Videti: Toril Moi, Seksualna/tekstualna politika. Feministička književna teorija, prevela s engleskog Maša Grdešić, AGM, Zagreb, 2007.

37 Više o projektu i časopisu: http://knjizenstvo.etf.bg.ac.rs/ i http://www.knjizenstvo.rs/magazine.php (25. 9. 2017). 
kacije). To, ponovo, ne znači da je došlo do bilo kakvih revolucionarnih promena u uređivačkoj politici časopisa u celini i da se u prethodnoj etapi njegovog razvoja domaćim ili regionalnim autorkama i autorima nije posvećivalo dovoljno pažnje. Naprotiv, kao što smo već istakli, cilj prethodnih urednica bio je taj da se časopis otvori za domaću i regionalnu produkciju, budući da su Ženske studije, njegova preteča, prevashodno predstavljale platformu za objavljivanje prevoda relevantnih, mahom zapadnih, teorijskih promišljanja (zahvaljujući čemu su takođe postale izuzetno važan i plodan projekat za generacije naučnica i naučnika u Srbiji i okolnim državama). Na osnovu predočene statistike, možemo zaključiti da je ovaj cilj i posle promene uredništva ostao aktuelan, te da predstavlja jednu od važnijih konstanti u uređivačkoj politici časopisa od njegovog početka do danas.

Druga važna konstanta, koja se već da naslutiti, tiče se sledeće činjenice: naime, većinu tekstova objavljenih u Generu napisale su žene, o ženama i za žene. Isto se može reći i za prikaze. Ipak, postoje izuzetni slučajevi u kojima muškarci pišu ili o (ko)autorskim studijama koje u celini potpisuju žene: Aleksandar Čarapić, "Uz prvi tom sabranih dela Rakije Hasan" (Ruqaiya Hasan: Language, Society and Consciousness, 1. tom serije "The Collected Works of Ruqaiya Hasan", priređivač J. J. Webster, London, Oakville: Equinox Publishing Ltd. 2005); Aleksandar Čarapić, "Ka artikulaciji sopstvenog feminističkog diskursa" (Mapiranje mizoginije u Srbiji I i II tom, uredila Marina Blagojević, Beograd: AŽIN, 2000. i 2005); Ognjen Kojanić, "Šta studije ekonomije mogu da nauče od feminizma?” (J. K. Gibson-Graham, The End of Capitalism [As We Knew It]: A Feminist Critique of Political Economy, University of Minnesota Press, Minneapolis, 2006; J. K. Gibson-Graham, A Postcapitalist Politics, University of Minnesota Press, Minneapolis, 2006); Nenad Knežević, "Novo čitanje ženskih likova antičkog mita" (Svetlana Slapšak, Antička miturgïja: žene, Biblioteka XX vek, Beograd, 2013), ili o koautorskim izdanjima i zbornicima koja obavezno uključuju i žene - Vladimir Petrović, "Novosti iz prošlosti” (Vojin Dimitrijević, prir., Novosti iz prošlosti: znanje, neznanje, upotreba i zloupotreba istorije, Beogradski centar za ljudska prava, Beograd, 2010) i Đorđe Božović, "Povratak strukturalne lingvistike" (Marlis Hellinger and Heiko Motschenbacher, eds. Gender Across Languages: The Linguistic Representation of Women and Men, Volume 4, John Benjamins, Amsterdam, 2015).

Izuzev nekolicine navedenih prikaza, sve ostale pišu žene, mada to ne važi nužno i za prikazana dela. $U$ dosta retkim slučajevima nailazimo na prikaze teorijskih knjiga muških autora koje urednice ča- 
sopisa prepoznaju kao "relevantne za područje feminističke teorije i studija kulture" ${ }^{8}$ (omeđeno i samim podnaslovom časopisa počev od 2008. godine). Među njima su tekstovi Mie Kisić - "Od skarabeja do cor commerciale: priča o srcu" (Ule Martin Hejstad, Kulturna istorija srca: od antike do danas, prevela Angela Drenovac, Izdavačka knjižarnica Zorana Stanojevića, Sremski Karlovci i Novi Sad, 2011) i Dine Čubrić - "Ka radikalnoj slobodi” (Žak Ransijer, Mržnja prema demokratiji, Karpos, Loznica, 2013). Mnogo češće, gotovo isključivo, reč je o osvrtima na studije, eseje i objavljena istraživanja koje su sprovele i napisale žene.

Prikazana literatura je raznovrsna. Na prvom mestu, reč je o pojedinačnim studijama ili zbornicima eseja iz oblasti "uže shvaćene" feminističke teorije, gde treba izdvojiti prikaze Adriane Zaharijević "Šta je ostalo od feminizma?" (Feministička sporenja: filozofska razmena - Šejla Benhabib, Džudit Batler, Nensi Frejzer i Drusila Kornel, Uvod Linda Nikolson, prevela Jelisaveta Blagojević, Beogradski krug, 2007) i Katarine Lončarević "Feministička opklada na telo" (Elizabet Gros, Promenljiva tela: ka telesnom feminizmu, prevela Tatjana Popović, Biblioteka Rod i kultura, Centar za ženske studije i istraživanje roda, Beograd, 2005), objavljene u periodu do 2007. godine, kao i, na primer, tekstove Vladanke Malešić - "Fundamentalizmi i ženska ljudska prava" (Marieme Heli-Lukas, Fundamentalizmi danas - feministički i demokratski odgovori, Žene u crnom, Beograd, 2008), Ive Nenić "Kategorija žene kao stecište istorije sporova" (Adriana Zaharijević, Postajanje ženom, Rekonstrukcija Ženski fond, Beograd, 2010) i Sande Stanković - "Sve/i smo mi majke" (Ana Vilenica, ur., Postajanje majkom u vreme neoliberalnog kapitalizma, uz)bu))na))), Beograd, 2013), da pomenemo tek neke među onim objavljenim u periodu posle 2008. godine. Pored toga, često se prikazuju i stručne studije iz oblasti sociologije, filozofije, istorije, antropologije, književne teorije, lingvistike i srodnih humanističkih disciplina koje su napisale žene i koje na različite načine ulaze u domen studija roda i studija kulture i postaju relevantna literatura za sve generacije feministkinja u Srbiji, bez obzira na njihovu matičnu disciplinu ili primarna interesovanja.

Zaslužena pažnja u rubrici "Prikazi” posvećuje se i izdanjima koja predstavljaju plod prethodno sprovedenih, često dugogodišnjih i iscrpnih, terenskih i statističkih istraživanja položaja žena u Srbiji i regionu, načina na koji se on konstituiše i održava obrazovnim i kulturnim politikama, sprovođenja načela rodne ravnopravnosti u praksi i slično.

38 Videti najave brojeva 16 i 17. 
U tom kontekstu, možemo izdvojiti sledeće prikaze: Marina Simić, "Analiza rodne dimenzije u srednjoškolskim i visokoškolskim udžbenicima" (Jana Baćević i drugi, Analiza rodne dimenzije u visokoškolskom obrazovnom materijalu, Program Ujedinjenih nacija za razvoj, Beograd, 2010; Dragana Stjepanović-Zaharijevski i drugi, Obrazovanje za rodnu ravnopravnost: analiza nastavnog materijala za osnovnu i srednju školu, Program Ujedinjenih nacija za razvoj, Beograd, 2010; Gorana Đorić, Natalija Žunić i Tatjana Obradović-Tošić, Obrazovanje za rodnu ravnopravnost: analiza nastavnog materijala za Građansko vaspitanje, Program Ujedinjenih nacija za razvoj, Beograd, 2010); Dragana Popović, "Istraživanje Građanke i građani Srbije o rodnoj ravnopravnosti: javno mnjenje Srbije o rodnoj ravnopravnosti” (Suzana Ignjatović i drugi, Građanke i građani Srbije o rodnoj ravnopravnosti: javno mnjenje Srbije o rodnoj ravnopravnosti, Centar za politikološka istraživanja i javno mnjenje, Beograd, 2010), kao i tekst Jelene Mićević Karanović - "Empirijski pristup toleranciji i rodnoj ravnopravnosti" (Dijana Subotički Miletić i Zoran Gavrilović, Tolerancija i rodna ravnopravnost u srednjim školama Kikinde, Banatski kulturni centar, Novo Miloševo, Udruženje građana Postpesimisti i Udruženje građana Centar za kulturu dijaloga, Kikinda, 2016).

Ono što je karakteristično za većinu prikaza, i što se takođe može smatrati svojevrsnom konstantom u uređivačkoj politici časopisa $\mathrm{Ge}$ nero, bez obzira na to da li je reč o njegovoj prvoj ili drugoj fazi, te da li su u pitanju prikazi stručne literature ili književnih ostvarenja, jeste svojevrsna blagonaklonost autorki i autora ove forme prema prikazanim tekstovima i njihovim autorkama i autorima. U tom pogledu, rubrika "Prikazi" upadljivo je "nepolemička", sa retkim izuzecima (kakve bi mogli predstavljati pomenuti tekstovi Katarine Lončarević o memoarima Gintera Grasa ili Hane Ćopić o Šlinkovom Čitaču, mada i oni samo donekle). Svi kritički komentari ujedno su panegirički, dok je oštrica negativne kritike uglavnom rezervisana samo za one pojave ili probleme sa kojima se određena autorka ili autor obračunava u knjizi koja se razmatra, dakle, za svaki oblik mizoginije, seksizma, nacionalizma i drugih vidova diskriminacije, što je u skladu sa uređivačkom politikom časopisa i radom Centra za ženske studije u celini.

Ovo nam govori da, pored toga što predstavlja jedan od najvažnijih časopisa na području Srbije koji ima za cilj da promoviše i artikuliše feminističku teorijsku misao i dostignuća domaće i strane stručne javnosti u domenu studija kulture i studija roda, Genero takođe predstavlja svojevrstan prostor umrežavanja, saradnje i međusobnog dijaloga između domaćih (i u ređim slučajevima regionalnih) autorki 
(i, ponovo, u ređim slučajevima autora). Taj i takav prostor možda na najočigledniji način predstavlja upravo rubrika "Prikazi". Iako tekstove u njoj objavljuju autorke i autori različitih profila, stepena obrazovanja, uzrasta, profesije ili interesovanja, primetno je da veliki deo njih čine već profilisane naučnice i naučnici, ali i da se značajan prostor daje mladim istraživačicama i istraživačima, studentkinjama i studentima koji neretko prvi put objavljuju upravo u ovoj rubrici. ${ }^{39}$ To je još jedna od konstanti uređivačke politike Genera, koju možemo pratiti od 2002. godine, kada Biljana Dojčinović i Jelisaveta Blagojević eksplicitno navode da "još jedna važna ideja u vezi sa Generom jeste nastojanje da postane prostor na kom će studentkinje i studenti zainteresovani za ove teme objavljivati svoje radove, podstičući i uvodeći tako i glasove mlade gen(d)er-acije". ${ }^{40}$ Ti glasovi najjače se čuju upravo u rubrici "Prikazi", u kojoj stupaju u dijalog sa glasovima drugih gen(d)er-acija i na izvestan način postaju njihov eho, omogućavajući im na taj način da se bolje čuju, ali i iskazujući zahvalnost njihovim prethodno učinjenim naporima da ova sfera postane polje feminističke borbe i feminističke misli.

\section{LITERATURA}

\section{Primarni izvori}

Genero: časopis za feminističku teoriju, br. 1 - 10/11: https://www. ceeol.com/search/journal-detail?id=833 (25. 9. 2017).

Genero: časopis za feminističku teoriju i studije kulture, br. 12 - 20: https://www.ceeol.com/search/journal-detail?id=833 (25. 9. 2017).

Portal Centra za ženske studije: http://www.zenskestudie.edu.rs (25. 9. 2017).

Akt o uređivanju naučnih časopisa, Centar za obrazovanje i evaluaciju u nauci, br. 79/05, Beograd, 2009.

\section{Sekundarna literatura}

Dojčinović, Biljana. "Feministička čitanja i preispitivanje književnog kanona”, Genero, br. 1, 2002, str. 36-42.

39 To, recimo, važi za pomenute prikaze Nede Radulović, Ane Kolarić, kao i za tekst “Aporije jezičke ideologije" Zorane Simić iz 19. broja.

40 http://www.zenskestudie.edu.rs/izdavastvo/casopis-genero/16-genero-casopisza-feministicku-teoriju-i-studije-kulture (25. 9. 2017). 
Dojčinović, Biljana. "Prihvatanje razlika: feministička kritika u Srbiji u postsocijalističkom periodu”, u ovom zborniku.

DuPlezi, Rejčel Blau. "Etrurkama”, Genero, br 1, 2002, str. 112-127.

Đurić, Dubravka. "Feministički i ženski časopisi u postjugoslovenskim kulturama”, ProFemina, specijalni broj, leto-jesen 2011, str. 263-282.

Dželen, Majra. “Arhimed i paradoks feminističke kritike”, Genero, br. 1, 2002, str. 73-96.

Feterli, Džudit. "O političkoj prirodi književnosti”, Genero, br. 1, 2002, str. 46-56.

Kolarić, Ana. "(Raz)govor o književnosti i feminizmu: rane kritike Rebeke Vest”, Knjiženstvo, časopis za studije književnosti, roda i kulture, Godina IV, broj 4, http://www.knjizenstvo.rs/magazine. php?text=132 (25. 9. 2017).

Kolodni, Anet. "Mapa ponovnog čitanja: rod i interpretacija književnih tekstova", Genero, br. 1, 2002, str. 58-71.

Lukić, Jasmina. "Međugeneracijski dijalog kao način putovanja teorije”, Treća, tema broja "Re/generacijski feminizmi”, 2015 XVII 1-2, str. 21-32.

Milivojević, Snježana. “Žene i mediji: strategije isključivanja”, Genero, posebno izdanje, 2004, str. 11- 24.

Papić, Žarana. "Od državnog socijalizma do državnog nacionalizma: slučaj Srbije iz rodne perspektive”, Žarana Papić, Tekstovi 19772002, ur. Adriana Zaharijević, Zorica Ivanović i Daša Duhaček, Beograd, 2012, str. 287-302.

Robinson, S. Lilijan. "Izdaja našeg teksta: feministički izazovi književnom kanonu”, Genero, br. 1, 2002, str. 97- 111.

\section{"GENERO" (2002-2016): SPECIFIC TOPICS AND LITERARY CRITICISM/REVIEWS}

In the 1990s, in Serbia and regionas well, in addition to feminist activism and its strong anti-war initiatives, one can also spot the awareness of the necessity of introducing a feminist theoretical approach. This idea was fulfilled in 1991 by the opening of the Women's Studies Center in Belgrade. Along with the opening of the Center its members have also had an idea of launching a 
journal (Women's Studies, and later Genero), which would help them to introduce and translate some fundamental concepts and essays of feminist theory in the context of post-Yugoslav states. This paper is about the creation and development of the journal Genero. In the first part of the essay special attention is paid to the main topics of some of the journal issues (an American feminist criticism will be presented in detail with the aim to show how important translating of foreign theoretical essays is for the development of regional feminist theory). The second part of the paper will be focused on (mostly scientific literature) reviews.

Keywords: Genero, main topics of the issues, reviews, feminist theory, feminist journals in Serbia 